PENGAKUAN DAN PENGESAHAN HAK PATEN UNTUK SUATU PRODUK YANG DIPASARKAN

\title{
Rully Nanang Septiawan 185100003P
}

Fakultas Komputer, KDV 448757211

rullynanang.student@umitra.ac.id

\begin{abstract}
Hak Paten adalah hak khusus yang diberikan negara kepada penemu atas hasil penemuannya di bidang teknologi, di mana untuk jangka waktu yang telah ditentukan melaksanakan sendiri penemuannya tersebut atau memberikan persetujuan kepada orang lain untuk melaksanakannya. Hak paten ini diberikan untuk penemuan baru yang mengandung langkah inventif dan dapat diterapkan dalam industri.

Hak paten ini bersifat ekslusif karena hanya inventor yang menghasilkan invensi saja yang dapat diberikan hak, namun inventor ini dapat melaksanakan sendiri invensinya tersebut atau memberi persetujuan kepada pihak lain untuk melaksanakannya, misalnya melalui lisensi.

Dalam UU No.14 Tahun 2001 Pasal 11 disebutkan bahwa yang dianggap sebagai inventor adalah seseorang atau beberapa orang yang untuk pertama kali dinyatakan sebagai inventor dalam permohonan. Jadi hak paten ini tidak hanya dimiliki oleh satu orang saja, namun hak peten ini dapat diberikan kepada beberapa orang terhadap suatu penemuan yang dilakukan secara bersama-sama dan atas permohonan pendaftaran hak paten dicantumkan nama-nama dari penemu tersebut. Jika dalam invensi tersebut ditemukan atas kerja sama, maka hak paten tersebut dimiliki secara kolektif.
\end{abstract}

Kata Kunci : Hak Paten 
A. INTRODUCTION

Materi Ke 1 membahas mengenai : Pengertian Hak Paten Menurut Para Pakar, sebagai berikut :

\section{Pengertian Hak Paten} menurut Octroiwet, Hak Paten adalah hak khusus yang diberi kepada seseorang atas permohonannya kepada orang itu yang menciptakan sebuah produk baru, cara kerja baru atau perbaikan baru dari produk atau dari cara kerja.

Menurut Adrian Sutedi, Pengertian Hak Paten adalah hak khusus yang diberikan negara kepada penemu atas hasil penemuannya di bidang teknologi, di mana untuk jangka waktu yang telah ditentukan melaksanakan sendiri penemuannya tersebut atau memberikan persetujuan kepada orang lain untuk melaksanakannya. Hak paten ini diberikan untuk penemuan baru yang mengandung langkah inventif dan dapat diterapkan dalam industri.

Dalam UU No. 14 Tahun 2001 mengenai paten, Pengertian Hak Paten adalah hak eksklusif yang diberikan negara kepada inventor atas hasil invensinya di bidang teknologi, di mana untuk selama jangka waktu tertentu melaksanakan sendiri invensinya tersebut atau memberikan persetujuannya kepada pihak lain untuk melaksanakannya.

Pengertian Invensi ialah ide inventor yang dituangkan ke dalam suatu kegiatan pemecahan masalah yang spesifik di bidang teknologi dapat berupa produk atau proses atau penyempurnaan dan pengembangan produk atau proses.
Dari pengertian hak paten di atas, dapat tarik kesimpulan bahwa Pengertian Hak Paten adalah hak bagi seseorang yang telah mendapat penemuan baru atau cara kerja baru dan perbaikannya dalam bidang teknologi yang diberikan oleh pemerintah, yang kepada pemegang haknya dibolehkan untuk menggunakannya sendiri atau atas izinnya mengalihkan penggunaan hak itu kepada orang lain.

Hak paten merupakan suatu hak khusus yang didasarkan pada UU yang diberikan kepada si penemu (uitvinder) atau menurut hukum pihak yang berhak memperolehnya atas permintaan yang diajukannya kepada pihak penguasa, bagi temuan baru di bidang teknologi, perbaikan atas temuan yang sudah ada, cara kerja baru atau menemukan suatu perbaikan baru dalam cara kerja, untuk selama jangka waktu tertentu yang dapat diterapkan dalam bidang industri.

Hak paten ini bersifat ekslusif karena hanya inventor yang menghasilkan invensi saja yang dapat diberikan hak, namun inventor ini dapat melaksanakan sendiri invensinya tersebut atau memberi persetujuan kepada pihak lain untuk melaksanakannya, misalnya melalui lisensi.

Dalam UU No.14 Tahun 2001 Pasal 11 disebutkan bahwa yang dianggap sebagai inventor adalah seseorang atau beberapa orang yang untuk pertama kali dinyatakan sebagai inventor dalam permohonan. Jadi hak paten ini tidak hanya dimiliki oleh satu orang saja, namun hak peten ini dapat 
diberikan kepada beberapa orang terhadap suatu penemuan yang dilakukan secara bersama-sama dan atas permohonan pendaftaran hak paten dicantumkan nama-nama dari penemu tersebut. Jika dalam invensi tersebut ditemukan atas kerja sama, maka hak paten tersebut dimiliki secara kolektif.

Hak kolektif itu selain diberikan kepada beberapa orang secara bersama-sama, dapat juga diberikan pada badan hukum. UU ini memakai titik tolak bahwa yang pertama kali mengajukan permintaan hak paten dianggap sebagai inventor. Apabila dikemudian hari terbukti sebaliknya secara kuat dan meyakinkan, maka status sebagai inventor tersebut dapat saja berubah sesuai dengan bukti-bukti hukum di pengadilan.

Dalam perjanjian kerja tidak mengharuskan karyawan atau pekerjanya untuk menghasilkan invensi, namun bila karyawan atau pekerja tersebut menghasilkan invensi dengan menggunakan data dan sarana yang tersedia dalam pekerjaannya, maka yang berhak memperoleh hak paten atas invensi tersebut adalah orang yang memberikan pekerjaan tersebut yaitu majikan.

Dapat saja invensi itu dihasilkan secara tidak dikehendaki lebih awal (tidak disengaja), namun karyawan yang memiliki kemampuan intelektualitas dan kreativitas yang tinggi dapat menghasilkan invensi yang dapat dimohonkan hak patennya. Dalam hal ini tidak adil jika hak itu kemudian menjadi milik majikan, hanya karena ia menggunakan fasilitas dari pihak majikan. Jika kita telusuti kembali pemaknaan tentang HAKI (Hak Kekayaan Intelektual) sebagai hasil karya cipata, rasa dan karsa, maka karyawan ini juga semestinya harus diberikan hak eksklusif atas invensinya tesebut.

Hak paten pada dasarnya merupakan perlindungan hukum bagi penemu atas penemuannya yang diberikan untuk jangka waktu tertentu. Perlindungan ini sesuai dengan sifat eksklusif yang dimilikinya, yang melarang orang lain untuk menggunakannya tanpa persetujuan dari pemegang hak paten atau melakukan tindakan lainnya yang bersifat pengambilan manfaat ekonomi dari suatu penemuan tanpa persetujuan dari pemegang paten.

Sekian mengenai pengertian hak paten dan pembahasannya, semoga tulisan saya mengenai pengertian hak paten dan pembahasannya dapat bermanfaat.

\section{B. CONCLUSION}

Kesimpulan dari materi ini adalah :

\section{Pengertian Hak Paten} menurut Octroiwet, Hak Paten adalah hak khusus yang diberi kepada seseorang atas permohonannya kepada orang itu yang menciptakan sebuah produk baru, cara kerja baru atau perbaikan baru dari produk atau dari cara kerja.

Menurut Adrian Sutedi, Pengertian Hak Paten adalah hak khusus yang diberikan negara kepada penemu atas hasil penemuannya di bidang teknologi, di mana untuk jangka waktu yang telah ditentukan melaksanakan sendiri penemuannya tersebut atau memberikan persetujuan kepada orang 
lain untuk melaksanakannya. Hak paten ini diberikan untuk penemuan baru yang mengandung langkah inventif dan dapat diterapkan dalam industri.

\section{ACKNOWLEDGEMENT}

University Of Indonesia University Of Mitra Indonesia

Telkom University University Of Mellbourne

Saitama University

\section{REFERENCE(Based ISO 690 )}

[1] A. S. Putra And O. M. Febriani, "Knowledge Management Online Application In Pdam Lampung Province," In Prosiding International Conference On Information Technology And Business (Icitb), 2018, Pp. 181-187.

[2] A. S. Putra, O. M. Febriani, And B. Bachry, "Implementasi Genetic Fuzzy System Untuk Mengidentifikasi Hasil Curian Kendaraan Bermotor Di Polda Lampung," J. Sist. Inf. Dan Manaj. Basis Data, Vol. 1, No. 1, Pp. 21-30, 2018.

[3] O. M. Febriani And A. S. Putra, "Sistem Informasi Monitoring Inventori Barang Pada Balai Riset Standardisasi Industri Bandar Lampung," J. Inform., Vol. 13, No. 1, Pp. 90-98, 2014.

[4] Putra, Arie Setya. "2018 Artikel Struktur Data, Audit Dan Jaringan Komputer." (2018).

[5] Putra, A. S. (2018, July 17). Paperplain Fundamental Create Application With Borland Delphi 7.0 University Of Mitra Indonesia. Retrieved From Osf.Io/Pbrn9. 


\section{E. REFERENCE(Based APA )}

Putra, A. S., Aryanti, D. R., \& Hartati, I. (2018, November). Metode SAW (Simple Additive Weighting) sebagai Sistem Pendukung Keputusan Guru Berprestasi (Studi Kasus: SMK Global Surya). In Prosiding Seminar Nasional Darmajaya (Vol. 1, No. 1, pp. 85-97).

Sari, D. P., Febriani, O. M., \& Putra, A. S. (2018, November). Perancangan Sistem Informasi SDM Berprestasi pada SD Global Surya. In Prosiding Seminar Nasional Darmajaya (Vol. 1, No. 1, pp. 289-294).

Putra, A. S. (2018). Paperplain: Execution Fundamental Create Application With Borland Delphi 7.0 University Of Mitra Indonesia.

Putra, A. S., Sukri, H., \& Zuhri, K. Sistem Monitoring Realtime Jaringan Irigasi Desa (JIDES) Dengan Konsep Jaringan Sensor Nirkabel. IJEIS (Indonesian Journal of Electronics and Instrumentation Systems), 8(2), 221232.

Darmawan, A., Yuliawati, D., Marcella, O., \& Firmandala, R. (2016). Sistem Absensi dan Pelaporan Berbasis Fingerprint dan SMS Gateway. EXPLORE, 7(1).

Febriani, O. M., Wahyuni, T., \& Yusuf, S. (2017). DESIGN OF WEBSITE-BASED INFORMATION SYSTEM FOR EDOCUMENT ADMINISTRASI IN THE COMMUNITY SERVICE UNIT (A Case Study at Rajabasa District). INTERNATIONAL JOURNAL OF
COMPUTERS \& TECHNOLOGY, 16(7), 7010-7020.

Febriani, O. M., \& Wahyuni, T. (2017, October). PERANCANGAN SISTEM E-DOCUMENT ADMINISTRASI LOGBOOK PENELITIAN PADA UNIT LAYANAN DI BANDAR LAMPUNG. In Prosiding Seminar Nasional Darmajaya (Vol. 1, No. 1, pp. 187-194).

Febriani, O. M., \& Permadi, A. B. (2017). Implementasi Sistem Aplikasi Data Bimbingan dan Pelanggaran Siswa pada Sekolah Menengah Atas di Lampung Tengah dengan Metode Analisis dan Desain Sistem Terdistribusi (SSAD). EXPERT, 7(1).

Febriani, O. M., \& Ambarwati, L. (2015). PERANCANGAN APLIKASI PENGOLAHAN DATA PENJUALAN UKM KELANTING KHAS TELO DESA SIDOHARJO KECAMATAN JATI AGUNG KABUPATEN LAMPUNG SELATAN. Jurnal Teknologi Informasi dan Bisnis Pengabdian Masyarakat Darmajaya, 1(1), 77-95.

Febriani, O. M. (2015). Rancang Bangun Aplikasi Ecommercemenggunakan Freewebstore pada UKM Kelanting di Desa Sidoharjo Lampung Selatan. Prosiding Sembistek 2014, 1(02), 446-458. 